\title{
THE IMPACT OF PRT ON ARMY BASE SUSTAINABILITY
}

\author{
Peter J. Muller, P.E.* \\ * President, PRT Consulting, Inc. 1340 Deerpath Trail, Ste 200, Franktown, CO 80116; PH 303- \\ 532-1855; pmuller@prtconsulting.com
}

\begin{abstract}
This study investigates the ability of a personal rapid transit (PRT) system to enhance sustainability at the Fort Carson Army Post in Colorado Springs, Colorado. Staff and stakeholder values are explored in relation to the implementation of PRT and alternative systems. Trade-offs between level of service, convenience, visual impact, etc. are weighed and the overall desirability of PRT is determined. Stations are located, a preferred alignment is developed and ridership is estimated. The system is modeled to determine guideway capacities, walk, wait and travel times as well as the number of transportation pods (T-Pods) required and its ability to carry sufficient passengers to meet the Post's goal for reducing single occupancy vehicle use. PRT benefits and costs are determined and compared. Recommendations are made regarding possible next steps to be taken toward implementing the PRT system.
\end{abstract}

\section{Introduction}

The Fort Carson community has adopted sustainability goals for the post, which include significant reductions in single occupancy vehicle (SOV) use. At the same time, the Post is experiencing significant growth, which potentially challenges its ability to meet the goals. In addition to encouraging people to share rides, the community is considering numerous alternatives to reduce SOV trips, including providing improved sidewalks and the use of low impact vehicles, such as bicycles and Segways. However, average on-post trip lengths are about $5.6 \mathrm{~km}$ (3.5 miles) long, and these alternatives will probably not always be appropriate (especially in times of inclement weather). Bus services on the Post have historically been poorly utilized and thus, traditional transportation options seem very limited in their ability to facilitate achieving the SOV goal.

Personal rapid transit (PRT) is a relatively new form of transit, which utilizes small, automated vehicles travelling on guideways, to transport passengers directly to their destinations, without stopping or transferring. It provides a high level of service more akin to an automobile than a bus. Due to the automation, PRT is relatively inexpensive to operate. However, the infrastructure involved requires considerable up front capital expenditure. PRT can carry significant numbers of people in all kinds of weather and, working with low impact vehicles, could potentially allow the Post to meet its SOV goal. The purpose of this study is to undertake a preliminary investigation of the feasibility of a PRT system, on the Fort Carson Army Post.

Considerable growth is planned at the Post, and this study is based on conditions as they are projected to be at build-out (approximately 2015) - also referred to, herein, as the Planning Year. 


\section{Comparison with Other Modes}

This section compares PRT with other modes of travel, from the point of view of existing Fort Carson commuters.

\section{Transportation Preferences of Fort Carson Commuters}

A Transit \& Parking Options Workshop, open to Fort Carson leaders, employees, residents, soldiers and community stakeholders, was held on October 1, 2008 from 0900 to 1500. There were 21 participants, of which one was a soldier living on post. Participants were exposed to descriptions of numerous transportation options. Most of these descriptions were fairly brief, since most options (such as buses) were already familiar to the participants. Where options were typically unfamiliar (such as PRT), a more in-depth description was provided. Participants were given the opportunity to ask questions and take part in discussions. During the workshop, participants responded to a number of questionnaires, the results of which are tabulated and discussed below.

Table 1. Travel Pattern Survey

\begin{tabular}{|c|c|c|c|}
\hline \multicolumn{4}{|c|}{ Travel Pattern Survey Summary } \\
\hline Survey \# & Description & $\begin{array}{l}\text { No. of Parking } \\
\text { Spaces used }\end{array}$ & Note \\
\hline 1 & PPACG Staff Member & 1 & Rarely visits Post \\
\hline 2 & Civilian & 3 & POV to/from post then GOV vehicle \\
\hline 3 & Civilian & 0 & Bus only \\
\hline 4 & Civilian & 0 & visits base 1 time per month via GOV \\
\hline 5 & Civilian & 5 & POV to/from post then GOV vehicle \\
\hline 6 & Student/Intern @ UCCS & 0 & N/A - did not consider base visit \\
\hline 7 & Civilian & 1 & POV only \\
\hline 8 & Civilian & 4 & POV only \\
\hline 9 & Civilian & 5 & POV \& GOV use \\
\hline 10 & Civilian & 2 & POV to/from post then GOV vehicle \\
\hline 11 & Civilian & 4 & POV only \\
\hline 12 & Civilian & 1 & POV only \\
\hline 13 & Civilian & 3 & POV only \\
\hline 14 & Civilian & 5 & POV to/from post then GOV vehicle \\
\hline 15 & Civilian & 3 & POV only \\
\hline 16 & Civilian & 3 & POV only \\
\hline 17 & Civilian & 2 & POV only \\
\hline 18 & Soldier Living On-Post & 6 & POV only \\
\hline 19 & Civilian & 2 & POV only \\
\hline 20 & Civilian & 2 & POV only \\
\hline 21 & Civilian & 2 & POV only \\
\hline \multicolumn{2}{|c|}{ Average Parking Stall Requirement } & 2.6 & \\
\hline
\end{tabular}

$\mathrm{POV}=$ privately-owned vehicle. GOV = government-owned vehicle

Table 1 categorizes the workshop participants. It also shows that people who drive on the post typically use more than one parking stall. In fact, if the four people, who indicated they rarely travel to the post or 
use the bus, are eliminated, the results indicate that drivers on the post use more than three parking spaces on average.

Table 2. Travel Preference Survey

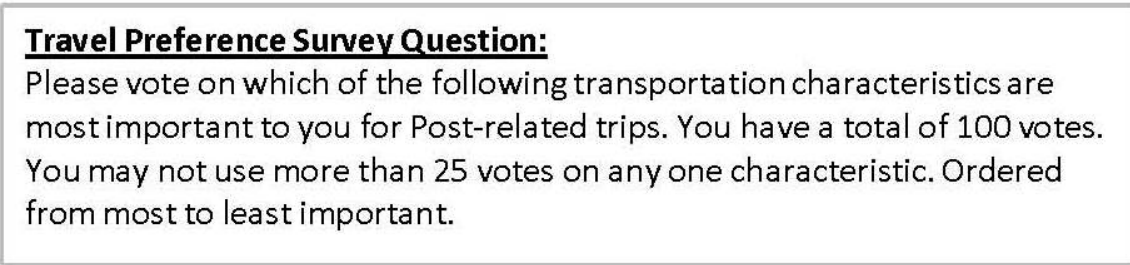

\begin{tabular}{|l|c|l|l|}
\hline \multicolumn{3}{|c|}{ Ordered Travel Preference Survey } & Analysis Results \\
\hline Reliable & 13.22 & Highest Priority \\
\hline Flexible Departure and Arrival & 10.22 & \\
\hline Low Cost & 9.50 & \\
\hline Easy to Use & 9.22 & \\
\hline Short Walking Distance & 7.72 & \\
\hline Short Waiting Time & 7.61 & \\
\hline Energy Efficient & 6.72 & \\
\hline Short Travel Time & 6.39 & \\
\hline Low Emissions & 4.56 & \\
\hline No transfers & 4.39 & \\
\hline Consistent Travel Time & 4.17 & \\
\hline Safe & 3.72 & \\
\hline Comfortable & 3.44 & \\
\hline Visually Appealing & 2.67 & \\
\hline Seated Travel & 2.28 & \\
\hline ADA Compliant (disabled persons access) & 1.94 & \\
\hline Personally Secure & 1.94 & \\
\hline Private & 0.28 & Lowest Priority \\
\hline & 100.00 & \\
\hline Median & 4.47 & \\
\hline Mean (Average) & 5.56 & \\
\hline Average Deviation & 2.91 & \\
\hline Standard Deviation & 3.48 & \\
\hline
\end{tabular}

This survey sought to discover which transportation characteristics were most important to participants. Prior to the survey, participants were given the opportunity to modify and/or add to the list of characteristics.

Since the focus of this study was on-Post travel, it was desired to calculate mode preference for on-Post trips only. Since there was insufficient time to have the participants do this, we (PRT Consulting) rated each Mode against each characteristic, shown in Table 2, on a scale of 1 (poor) to 5 (excellent). For example, the mode "bicycle" was rated 5 for low emissions and 2 for safety. Note that we assumed trip lengths of 0.8 to $16 \mathrm{~km}$ (1/2 to 10 miles). 
Table 3. Mode Preference

\begin{tabular}{|l|c|}
\hline \multicolumn{2}{|c|}{ Mode Preference } \\
\hline \multicolumn{2}{|c|}{ Mode } \\
\hline Personal Rapid Transit & Score \\
\hline Low Impact Vehicle & 561 (Best) \\
\hline Car & 588 \\
\hline Bicycle & 540 \\
\hline Walk & 532 \\
\hline Jitney & 467 \\
\hline Light Rail & 467 \\
\hline Monorail & 451 \\
\hline Commuter Rail & 451 \\
\hline Paratransit & 443 \\
\hline Maglev & 443 \\
\hline Heavy Rail & 435 \\
\hline High Speed Rail & 435 \\
\hline Bus Rapid Transit & 403 \\
\hline Express / Regional Bus & 387 \\
\hline Shuttle Bus & 387 \\
\hline Local Bus & 346 (Worst) \\
\hline
\end{tabular}

Each rating was then multiplied by the average number of votes that characteristic received. For example, the bicycle rating of 5 for low emissions was multiplied by the 4.56 average vote for low emissions, for a score of 22.8. The scores for each mode and each characteristic were then added to arrive at the score in Table 3 (540 for bicycle).

The table has been colored to highlight the interesting result, that all small vehicle modes outscored all rail modes, which in turn outscored all bus modes (except paratransit).

In summary, although the attendance was insufficient and too homogenous to provide scientifically valid data, there was fairly clear evidence of preference for small vehicle modes and resistance to bus modes.

\section{PRT Layout}

Figure 1 shows the proposed PRT guideway layout and station locations. The layout was developed keeping the following considerations in mind:

- The layout was constrained to those areas of the Post generating the most traffic. For this reason zones 5 and 6 in Figure 1 are not served. Arrows at gates 1, 2, 4 and 20 are indicative of the desire to connect to other transit systems and/or to expand the PRT system off post at some future date.

- Stations were located in such a way that walking distances exceeding $1 / 4$ mile were avoided to the extent reasonable.

- Stations were located close to proposed low-impact vehicle share locations where feasible.

- One-way guideways were laid out connecting the stations and avoiding existing structures.

- Guideway directions were determined so as to minimize out-of-the-way travel to the extent reasonably possible. In some instances, connecting loops were inserted that do not serve stations, but serve only to facilitate reversal of direction of travel.

The layout depicted is necessarily approximate. The scope of work in this project did not allow for detailed design and the layout was only developed to the extent necessary to determine system requirements and approximate costs. Prior to implementation, much additional work will be required in order to finalize station and guideway locations and details. It will be desirable to ensure that the guideways and stations fit in well with the existing infrastructure and do not impact historic foot traffic 


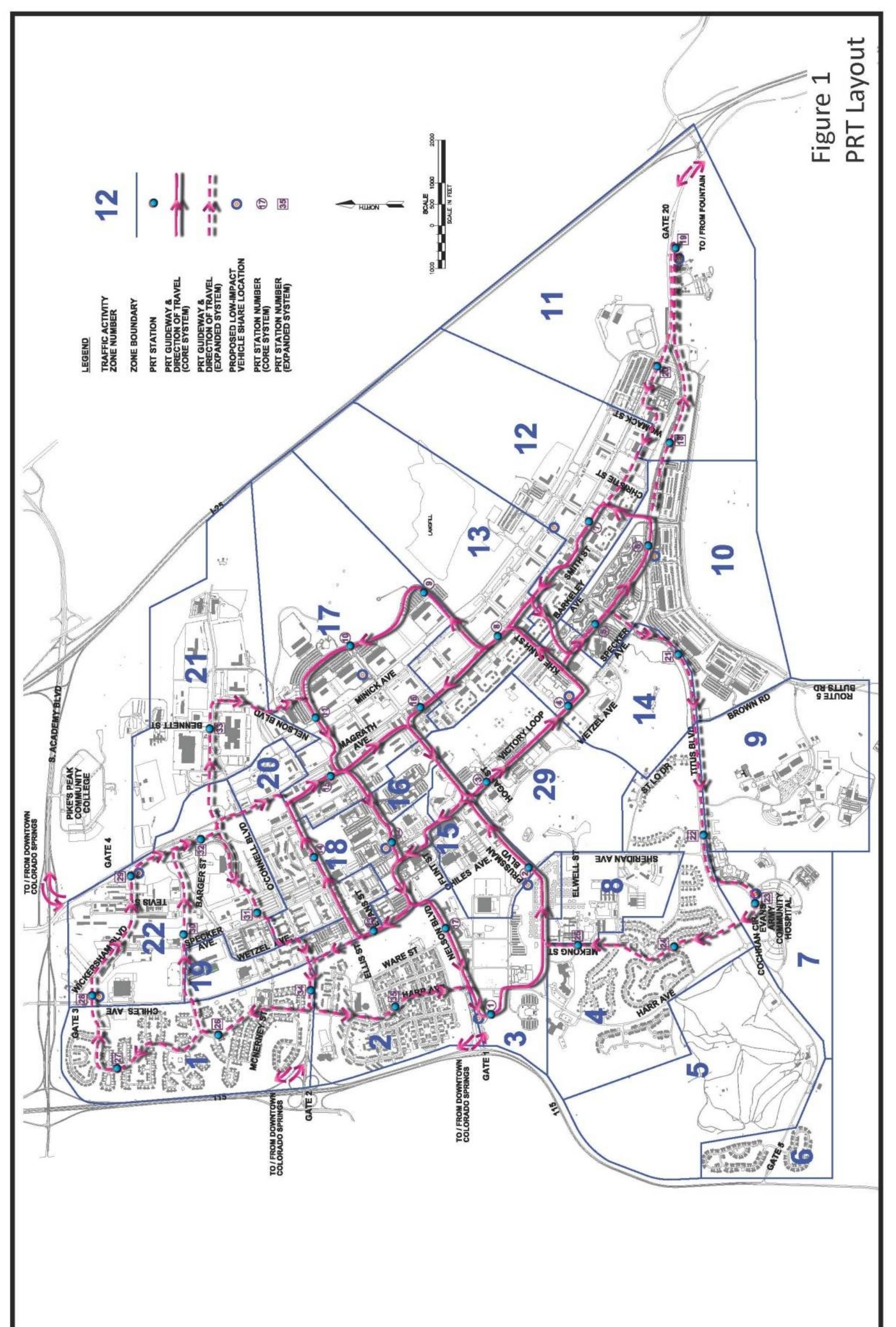


costs. The addition of over-/under-passes at key intersections should be investigated to determine the impacts on capacity, number of T-Pods required and trip times. It is anticipated that this could have a significant positive impact on the circuitousness of PRT trips.

At this time, it has been assumed that $20 \%$ of the guideway and stations will be at grade, and the remainder will be elevated.

PRT stations at entrance gates have been located inside the secure perimeter. It has been assumed that parking lots will be located outside the secure perimeter (but within the Post fencing system). PRT users will then walk through security to enter the station. Mr. Carl Backus (1) has confirmed that this arrangement will alleviate some of the screening burden and reduce the need to enlarge the gate facilities. If the PRT system is ever expanded to travel off-Post, it is envisioned that riders entering the post will exit their T-Pod to be screened and then enter a different T-Pod to continue their journey, thus, greatly reducing the requirement to inspect the T-Pods themselves. Load cells on the vehicles can sense objects left in the vehicles down to $4 \mathrm{~kg}$ (10 lbs.), and this capability can be backed up by on-board CCTV, coupled with left luggage detection software. In this way, allowing T-Pods to enter the post should be less risky than allowing automobiles to do so.

Where PRT stations are adjacent to low impact vehicle (LIV) share locations, it is envisioned that the LIVs will be utilized to extend the reach of the PRT system. For example, at station 23, the LIVs could be used by the disabled to get closer to the portion of the hospital they are visiting. Alternatively, they could be used to facilitate access to zones 5 and 6, which are not served by the PRT system. LIV vehicles should be of low speed and/or restricted from road travel, to avoid them being used in place of the PRT system and, thus, potentially causing traffic problems.

Stations 1 through 17, together with their associated $17.1 \mathrm{~km}$ (10.7 miles) of guideway, are envisioned as the core PRT system - large enough to have a significant impact, yet about half the size of the expanded system with its 35-station, $36.6 \mathrm{~km}$ (22.9 miles) of guideway. It is interesting to note the core system will only carry $18 \%$ of the traffic that the expanded system will carry, using the same ridership assumptions. This is because doubling the number of stations effectively quadruples the number of station pairs available and, thus, the utility of the system.

\section{PRT Ridership}

The Fort Carson Community has a sustainability goal of reducing non-mission SOV trips by $40 \%$, by the Planning Year. No data is available for this study as to the percentage of mission vs. non-mission trips. All trips have, therefore, been assumed to be non-mission. Since the United States has a very poor record of persuading people to reduce SOV trips by offering conventional alternatives, it has been assumed that the PRT system will have to carry the bulk of the diverted trips, in order for the goal to be met. Since the LIV system is planned for an $8 \%$ mode share, the mode share of PRT must be $32 \%$. This mode share is unlikely to be achieved without some type of PRT incentive/automobile disincentive program. Such a program is beyond the scope of this study, but has been assumed to be feasible. 


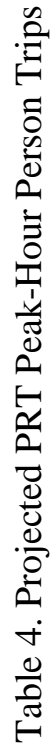

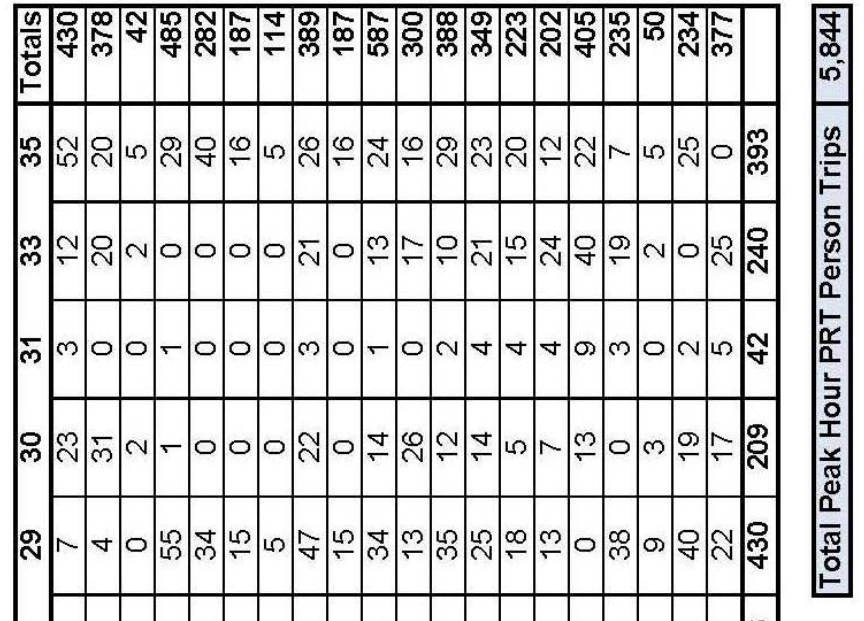

$\underset{\infty}{\infty} \infty$ N

ลัล

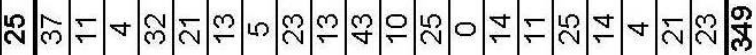

กิก

$\bar{N} \div$ ○

잉 ๓

$\because m$ m $00 \%$ ก

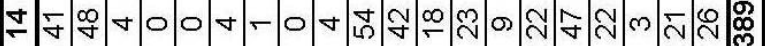

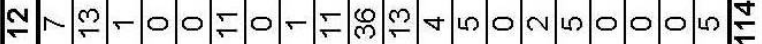

- m m - o o o f +

๓

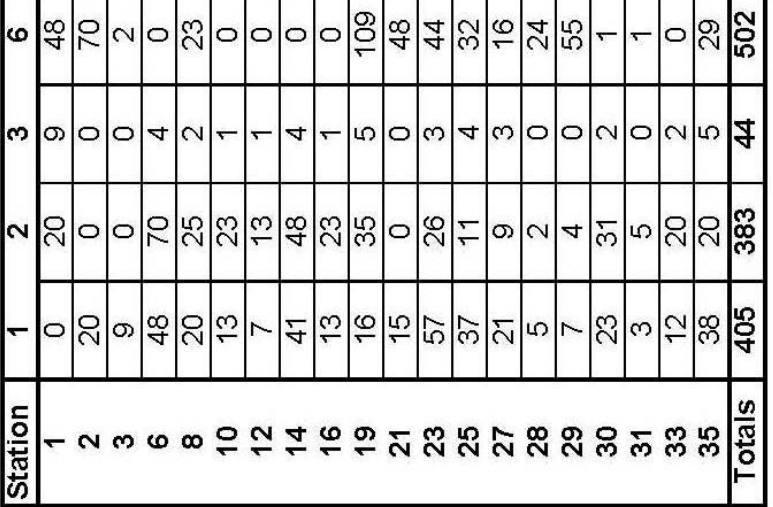


Table 4 shows projected peak-hour, station-to-station, person trips the PRT system would need to accommodate. This demand matrix was derived from the inter-zonal trip demand matrix, provided by Jacobs Consultancy, showing projected average daily person trips between each transportation analysis zone (TAZ) for the Planning Year. To account for the proportion expected to use PRT, the trips were factored by 32\%. This resulted in a daily projected PRT ridership of 53,500. Multiplying by 365 provided the expected annual ridership of 19.5MM.

The daily person trips were then multiplied by $10 \%$ plus a $10 \%$ contingency factor, in order to develop the matrix of peak hour trips shown in Table 4 . Ten percent of average daily trips is a commonly used factor (confirmed by Jacobs Consultancy) to determine peak hour trips. Since no data was available regarding the peak hour directional split, one was not applied, but a 10\% contingency factor was added. This is to say that the peak hour traffic was assumed to be equal in both directions. This probably underestimates the flows in the vicinity of the gates. However, the flows in the interior of the network are larger and more likely to be equal in both directions.

\section{PRT System Requirements}

In order to meet the demands outlined in this report, the PRT system will need to meet the following requirements:

- $29.3 \mathrm{~km}$ (18.3 miles) of elevated one-way guideway (excluding station access guideways)

- $7.4 \mathrm{~km}$ (4.6 miles) of at-grade guideway (excluding station access guideways)

- 28 elevated stations

- 7 at-grade stations

- 800 T-Pods, each capable of transporting at least three adults and their luggage, and operating at 25mph, with headways (time between T-Pods) as low as three seconds

- Capable of accommodating a 32\% mode share

o 19.5 million annual passengers

o 53,500 average daily passengers

o 6,000 peak hour passengers

In order to determine if the PRT layout depicted in Figure 1 could accommodate 6,000 peak hour passengers, the system was simulated using NETSIMMOD, a proprietary PRT simulation program developed by PRT Consulting. It was found that these passengers can be accommodated at a T-Pod average occupancy rate of 2.0 and a minimum operating headway (time between T-pods) of 3 seconds. The average occupancy rate of 2.0 has been assumed, based on the expectation that some ride sharing can be encouraged and will occur - particularly during the peak hour. If riders are charged for PRT use, this can be done on a per-vehicle rather than per-person basis, thus, encouraging ride sharing. In addition (for example), in the evening peak, many trips will have a gate station as a common destination, and riders waiting for a T-Pod are likely to offer to share rides. An off-peak occupancy rate of 1.1 has been assumed, yielding an average occupancy rate of $1.37(2.0 \times 30 \%+1.1 \times 70 \%)$. 
The following four tables show NETSIMMOD results from simulations run with differing values for TPod occupancy, minimum headway and total number of T-Pods. As can be seen, there are a number of different ways that a PRT system can achieve satisfactory results (average wait time under one minute, less than $10 \%$ waiting more than three minutes and in-vehicle delays under 30 seconds). The configuration shown in Table 5 is the one that has been adopted for the purposes of this report. It shows that 700 active T-Pods are required in order to provide satisfactory service levels. In order to allow for contingencies and maintenance needs it has been assumed that a total of 800 T-Pods will be needed.

Table 5. PRT Simulation with 3 second headway, 2.0 occupancy and 700 T-Pods

\begin{tabular}{|c|c|c|c|c|c|c|c|c|c|c|c|c|c|c|c|}
\hline \multicolumn{16}{|c|}{ NETSIMMOD - Data Summary } \\
\hline $\begin{array}{l}\text { Time } \\
\text { (min) }\end{array}$ & $\begin{array}{r}\text { Pax } \\
\text { Processed }\end{array}$ & $\begin{array}{l}\text { Ave } \\
\text { Wait } \\
\text { Secs }\end{array}$ & $\begin{array}{l}\text { Max } \\
\text { Wait } \\
\text { Secs }\end{array}$ & \begin{tabular}{|r|}
$\%$ \\
Waitin \\
$\mathrm{g}>1$ \\
min
\end{tabular} & \begin{tabular}{|r|}
$\%$ \\
Waitin \\
$\mathrm{g}>3$ \\
min
\end{tabular} & $\begin{array}{c}\text { No. of } \\
\text { T-Pod } \\
\text { Trips }\end{array}$ & \begin{tabular}{l|} 
Pax \\
Km/ \\
Veh \\
KM
\end{tabular} & $\begin{array}{r}\text { Ave } \\
\text { Delay } \\
\text { Secs }\end{array}$ & $\begin{array}{r}\text { No. of } \\
\text { Inline } \\
\text { Stations }\end{array}$ & $\begin{array}{r}\text { No. of } \\
\text { Offline } \\
\text { Stations }\end{array}$ & $\begin{array}{r}\text { Total } \\
\text { Guideway } \\
\text { Length }\end{array}$ & $\begin{array}{r}\text { No. of T- } \\
\text { Pods }\end{array}$ & $\begin{array}{lr}\text { Max } & \text { T- } \\
\text { Pod Occ }\end{array}$ & $\begin{array}{r}\text { Ave } \\
\text { T-Pod } \\
\text { Occ }\end{array}$ & $\begin{array}{r}\text { Min } \\
\text { Head } \\
\text { way }\end{array}$ \\
\hline $0-15$ & 1430 & 7 & 264 & 10 & 2 & 503 & 0.00 & 0 & 0 & 35 & 41145 & 700 & 4 & 2 & 3.00 \\
\hline $15-30$ & 1578 & 21 & 600 & 26 & 8 & 1128 & 1.60 & 4 & \multicolumn{2}{|c|}{ Wave-Offs } & & Pax KM & Veh KM & & \\
\hline $30-45$ & 1567 & 23 & 369 & 29 & 10 & 1116 & 1.52 & 4 & Occ. & Unocc. & & 34,082 & 21,925 & & \\
\hline $45-60$ & 1478 & 18 & 423 & 23 & 8 & 1125 & 1.58 & 4 & 0 & 0 & & & & & \\
\hline $60-75$ & 1561 & 14 & 612 & 22 & 2 & 667 & 1.51 & 6 & & & & & & & \\
\hline $15-75$ & 6184 & 19 & 612 & 25 & 7 & 4036 & 1.55 & 5 & \multicolumn{2}{|c|}{ Max Delay = } & 34 & & & & \\
\hline
\end{tabular}

The first column of each table shows five quarter-hour (15 minute) time intervals and one, one-hour (60 minute) time interval. The first fifteen minutes (row labeled 0-15) is used for the simulation to settle down. The following four fifteen-minute intervals are summarized in the last row (labeled 15-75). The first column shows the number of people processed. The second column shows the average waiting time in seconds. The third column shows the maximum time anyone had to wait. The system analyzed here needs some optimization, since maximum wait times should not exceed five minutes (300 seconds). The next two columns show the percent of people waiting more than one and three minutes respectively. The No. of T-Pod trips is the total number, including empty vehicle movement. Pax $\mathrm{Km} / \mathrm{Veh} \mathrm{Km}$ is the ratio of passenger kilometers travelled to vehicle kilometers travelled. The average delay and maximum delay are in-vehicle delay times. These account for delays a T-Pod may have in leaving or entering a station.

Table 6. PRT Simulation with 3 second headway, 1.5 occupancy and 800 T-Pods

\begin{tabular}{|c|c|c|c|c|c|c|c|c|c|c|c|c|c|c|c|}
\hline \multicolumn{16}{|c|}{ NETSIMIMOD - Data Summary } \\
\hline $\begin{array}{l}\text { Time } \\
\text { (min) }\end{array}$ & $\begin{array}{r}\text { Pax } \\
\text { Processed }\end{array}$ & $\begin{array}{r}\text { Ave } \\
\text { Wait } \\
\text { Secs }\end{array}$ & $\begin{array}{l}\text { Max } \\
\text { Wait } \\
\text { Secs }\end{array}$ & $\begin{array}{r}\% \\
\text { Waitin } \\
g>1 \\
\text { min }\end{array}$ & $\begin{array}{r}\% \\
\text { Waitin } \\
\mathrm{g}>3 \\
\text { min }\end{array}$ & $\begin{array}{r}\text { No. of } \\
\text { T-Pod } \\
\text { Trips }\end{array}$ & $\begin{array}{c}\text { Pax } \\
\text { Km/ } \\
\text { Veh } \\
\text { KM }\end{array}$ & $\begin{array}{r}\text { Ave } \\
\text { Delay } \\
\text { Secs }\end{array}$ & $\begin{array}{r}\text { No. of } \\
\text { Inline } \\
\text { Stations }\end{array}$ & $\begin{array}{r}\text { No. of } \\
\text { Offline } \\
\text { Stations }\end{array}$ & $\begin{array}{r}\text { Total } \\
\text { Guideway } \\
\text { Length }\end{array}$ & $\begin{array}{r}\text { No. of T- } \\
\text { Pods }\end{array}$ & $\begin{array}{c}\text { Max T- } \\
\text { Pod Occ }\end{array}$ & $\begin{array}{r}\text { Ave } \\
\text { T-Pod } \\
\text { Occ }\end{array}$ & $\begin{array}{r}\text { Min } \\
\text { Head } \\
\text { way }\end{array}$ \\
\hline $0-15$ & 1493 & 15 & 273 & 17 & 2 & 1065 & 0.00 & 0 & $\overline{0}$ & 35 & 41145 & 800 & 4 & 1.5 & 3.00 \\
\hline $15-30$ & 1475 & 33 & 360 & 32 & 10 & 1108 & 1.28 & 6 & \multicolumn{2}{|c|}{ Wave-Offs } & & Pax KM & Veh KM & & \\
\hline $30-45$ & 1551 & 37 & 384 & 39 & 13 & 1128 & 1.39 & 5 & Occ. & Unocc. & & 34,369 & 25,765 & & \\
\hline $45-60$ & 1545 & 50 & 636 & 39 & 23 & 1217 & 1.29 & 5 & 0 & 0 & & & & & \\
\hline $60-75$ & 1594 & 47 & 738 & 41 & 16 & 1182 & 1.38 & 6 & & & & & & & \\
\hline $15-75$ & 6165 & 42 & 738 & 38 & 15 & 4635 & 1.33 & 6 & \multicolumn{2}{|c|}{ Max Delay = } & 174 & & & & \\
\hline
\end{tabular}

Table 6 shows that reducing the average occupancy (of occupied vehicles) requires approximately one hundred more T-Pods, to reach a similar level of service, to that indicated in Table 5. 
Table 7. PRT Simulation with 2 second headway, 2.0 occupancy and 700 T-Pods

\begin{tabular}{|c|c|c|c|c|c|c|c|c|c|c|c|c|c|c|c|}
\hline \multicolumn{16}{|c|}{ NETSIMMOD - Data Summary } \\
\hline $\begin{array}{l}\text { Time } \\
\text { (min) }\end{array}$ & $\begin{array}{r}\text { Pax } \\
\text { Processed }\end{array}$ & $\begin{array}{c}\text { Ave } \\
\text { Wait } \\
\text { Secs }\end{array}$ & $\begin{array}{l}\text { Max } \\
\text { Wait } \\
\text { Secs }\end{array}$ & \begin{tabular}{|r|}
$\%$ \\
Waitin \\
$g>1$ \\
min
\end{tabular} & \begin{tabular}{|r|}
$\%$ \\
Waitin \\
$\mathrm{g}>3$ \\
min
\end{tabular} & $\begin{array}{c}\text { No. of } \\
\text { T-Pod } \\
\text { Trips }\end{array}$ & $\begin{array}{l}\text { Pax } \\
\text { Km/ } \\
\text { Veh } \\
\text { KM }\end{array}$ & $\begin{array}{r}\text { Ave } \\
\text { Delay } \\
\text { Secs }\end{array}$ & $\begin{array}{r}\text { No. of } \\
\text { Inline } \\
\text { Stations }\end{array}$ & $\begin{array}{r}\text { No. of } \\
\text { Offline } \\
\text { Stations }\end{array}$ & $\begin{array}{r}\text { Total } \\
\text { Guideway } \\
\text { Length }\end{array}$ & $\begin{array}{r}\text { No. of T- } \\
\text { Pods }\end{array}$ & $\begin{array}{l}\text { Max T- } \\
\text { Pod Occ }\end{array}$ & $\begin{array}{r}\text { Ave } \\
\text { T-Pod } \\
\text { Occ }\end{array}$ & $\begin{array}{r}\text { Min } \\
\text { Head } \\
\text { way }\end{array}$ \\
\hline $0-15$ & 1368 & 9 & 244 & 16 & 1 & 1101 & 0.00 & 0 & 0 & 35 & 41145 & 700 & 4 & 2 & 2.00 \\
\hline $15-30$ & 1515 & 16 & 246 & 23 & 2 & 1210 & 1.28 & 3 & \multicolumn{2}{|c|}{ Wave-Offs } & & Pax KM & Veh KM & & \\
\hline $30-45$ & 1607 & 18 & 626 & 28 & 4 & 1312 & 1.26 & 3 & Occ. & Unocc. & & 35,012 & 26,143 & & \\
\hline $45-60$ & 1562 & 10 & 738 & 14 & 0 & 1206 & 1.44 & 3 & 0 & 0 & & & & & \\
\hline $60-75$ & 1576 & 13 & 224 & 18 & 1 & 1319 & 1.38 & 3 & & & & & & & \\
\hline $15-75$ & 6260 & 14 & 738 & 21 & 2 & 5047 & 1.34 & 3 & \multicolumn{2}{|c|}{ Max Delay = } & 72 & & & & \\
\hline
\end{tabular}

Table 7 indicates that reducing the headway to two seconds provides no improvement over Table 5, which had identical parameters, except for a three-second headway. This is an indication that the guideways are not overloaded.

Table 8. PRT Simulation with 2 second headway, 1.5 occupancy and 800 T-Pods

\begin{tabular}{|c|c|c|c|c|c|c|c|c|c|c|c|c|c|c|c|}
\hline \multicolumn{16}{|c|}{ NETSIMIMOD - Data Summary } \\
\hline $\begin{array}{l}\text { Time } \\
\text { (min) }\end{array}$ & $\begin{array}{r}\text { Pax } \\
\text { Processed }\end{array}$ & $\begin{array}{r}\text { Ave } \\
\text { Wait } \\
\text { Secs }\end{array}$ & $\begin{array}{l}\text { Max } \\
\text { Wait } \\
\text { Secs }\end{array}$ & \begin{tabular}{|r|}
$\%$ \\
Waitin \\
$\mathbf{g}>1$ \\
min
\end{tabular} & $\begin{array}{r}\% \\
\text { Waitin } \\
\mathrm{g}>3 \\
\text { min }\end{array}$ & $\begin{array}{r}\text { No. of } \\
\text { T-Pod } \\
\text { Trips }\end{array}$ & $\begin{array}{l}\text { Pax } \\
\text { Km/ } \\
\text { Veh } \\
\text { KM }\end{array}$ & $\begin{array}{r}\text { Ave } \\
\text { Delay } \\
\text { Secs }\end{array}$ & $\begin{array}{r}\text { No. of } \\
\text { Inline } \\
\text { Stations }\end{array}$ & $\begin{array}{r}\text { No. of } \\
\text { Offline } \\
\text { Stations }\end{array}$ & $\begin{array}{r}\text { Total } \\
\text { Guideway } \\
\text { Length }\end{array}$ & $\begin{array}{r}\text { No. of T- } \\
\text { Pods }\end{array}$ & $\begin{array}{l}\text { Max T- } \\
\text { Pod Occ }\end{array}$ & $\begin{array}{r}\text { Ave } \\
\text { T-Pod } \\
\text { Occ }\end{array}$ & $\begin{array}{r}\text { Min } \\
\text { Head } \\
\text { way }\end{array}$ \\
\hline $0-15$ & 1394 & 15 & 222 & 18 & 1 & 1133 & 0.00 & 0 & 0 & 35 & 41145 & 800 & 4 & 1.5 & 2.00 \\
\hline $15-30$ & 1576 & 19 & 374 & 20 & 1 & 1253 & 1.23 & 3 & \multicolumn{2}{|c|}{ Wave-Offs } & & Pax KM & Veh KM & & \\
\hline $30-45$ & 1538 & 20 & 294 & 26 & 1 & 1224 & 1.27 & 4 & Occ. & Unocc. & & 35,742 & 27,978 & & \\
\hline $45-60$ & 1592 & 34 & 512 & 34 & 8 & 1233 & 1.34 & 3 & 0 & 11 & & & & & \\
\hline $60-75$ & 1585 & 33 & 476 & 35 & 9 & 1327 & 1.27 & 3 & & & & & & & \\
\hline $15-75$ & 6291 & 27 & 512 & 28 & 5 & 5037 & 1.28 & 3 & \multicolumn{2}{|c|}{ Max Delay = } & 107 & & & & \\
\hline
\end{tabular}

Similarly, Table 8 indicates that reducing the headway to two seconds provides no improvement over Table 6, which had identical parameters, except for a three-second headway.

\section{Benefit/Cost Analysis}

This section compares the benefits of a PRT system with the costs, in order to determine economic feasibility. PRT and new park \& ride facility capital costs were summed and then reduced by road and parking expansion costs that will no longer be needed. The net capital costs were then annualized over a forty-year life at an interest rate of 6\%. PRT O\&M costs were increased by new park and ride O\&M costs estimated at $5 \%$ of the capital costs per year. PRT costs were adjusted after communication with two PRT vendors.

Savings in road and parking lot maintenance were estimated at 5\% of the capital costs per year. Surveys and calculations were made to estimate congestion and delay reduction costs (2) due to the PRT system during normal and adverse weather conditions (3). Savings in automobile costs were estimated (4). 
Lifecycle emissions, including emissions during petroleum extraction and refining, vehicle manufacturing and maintenance, as well as roadway construction and maintenance were estimated and the associated costs determined (5). Muller (6) found that PRT is approximately 100 times safer than other modes but a factor of ten was used in estimating annual savings in accident costs (7). Fare box revenues were estimated based on a \$2.00 per trip fare (similar to Denver light rail fares). Since government employees receive a \$115 per month transit allowance this should not be a hardship for soldiers and other government employees.

The quantifiable costs and benefits are summarized below in millions (MM) of dollars.

Costs:

Annualized net capital costs

$\$ 15,42 \mathrm{MM}$

Annual net O\&M costs

$\$ 26.12 \mathrm{MM}$

Benefits (savings):

Total annual costs

$\$ 41.54 \mathrm{MM}$

Savings in annual road and parking maintenance costs

\$9.37MM

Savings in travel time

$\$ 48.65 \mathrm{MM}$

Savings in automobile costs

$\$ 31.69 \mathrm{MM}$

Savings due to emission reductions

$\$ 5.78 \mathrm{MM}$

Savings in accident costs

$\$ 21.61 \mathrm{MM}$

Fare box revenues

$\$ 39.05 \mathrm{MM}$

Total annual savings (benefits)

\$156.15MM

The benefit/cost ratio is 3.76. This indicates a significant benefit (personal, societal and/or governmental) and implies that large changes would need to be made in the data, analysis and/or assumptions used for this proposed PRT system, not to be feasible from a benefit/cost point of view.

\section{Conclusions and Recommendations}

Based on the preliminary study undertaken, a PRT system at Fort Carson appears to be feasible and has a highly favorable benefit/cost ratio. Most remarkably, it appears that the potential fare-box revenue could not only cover the operating costs, but also the majority of the annualized capital costs. This is unheard of in conventional public transit, where fares are typically subsidized, just to cover operating costs.

To put this project in perspective, it is compared to the recently-funded Salt Lake City Mid-Jordan Light Rail Extension (8) and the Dulles Rail Project (9) and in Table 9 below.

Table 9.

\begin{tabular}{|l|c|c|c|}
\hline & $\begin{array}{c}\text { Mid-Jordan LRT } \\
\text { Extension }\end{array}$ & Dulles Rail Project & $\begin{array}{c}\text { Fort Carson PRT } \\
\text { Project }\end{array}$ \\
\hline Miles of track & 11 (two-way) & 23 (two-way) & 23 (one-way) \\
\hline Stations & 9 & 11 & 35 \\
\hline Daily passengers & 9,500 & 60,000 & 53,500 \\
\hline Capital cost & $\$ 428,300,000$ & $\$ 5,200,000,000$ & $\$ 529,420,000$ \\
\hline
\end{tabular}


Clearly this appears to be a very viable transit project. However, this initial study was of limited scope and did not address all issues, nor was the work undertaken of sufficient depth to provide a fully credible result. In addition, while the project is economically viable, funding and financing mechanisms need to be established before it can proceed.

While funding and financing are key hurdles to be overcome, it appears that these may not be insurmountable obstacles. The PRT project should obviate the need for some \$23MM presently-planned road expansion projects, and these funds could potentially be used to seed the project leaving \$15.42MM in annualized net capital costs. If the annual maintenance costs of \$26.12MM are reduced by the savings in annual road and parking maintenance costs of $\$ 9.37 \mathrm{MM}$, the total annual net operating and capital costs are $\$ 32.17 \mathrm{MM}(\$ 15.42+26.12-9.37 \mathrm{MM})$. To cover this cost, each of the 19.5MM annual passengers would need to pay a fare of $\$ 1.65$. This fare-box revenue could be used to finance the project, but fares by themselves are typically insufficient for bonding of conventional transit projects.

It appears that this project will pay for itself in deferred capital and operating costs, for other projects no longer needed and in revenues from fares. However, mechanisms for utilizing the savings and revenues to finance the project will have to be found.

This study has shown that a PRT system could bring significant benefits to the Soldiers and people living and/or working on the Post. When monetized, these benefits far outweigh the system's costs. A PRT system would go a long way towards allowing the Post to meet its transportation-related sustainability goals. The sprawling nature of the present development on the Post is such as to not be conducive to a PRT system. The positive results of this study are, thus, somewhat surprising and indicate a potential for PRT to have beneficial transport and sustainability impacts in other military or civilian developments of similar type.

\section{Bibliography}

1. Meeting with Carl Backus, Chief, Physical security Branch and Richard Orphan, Traffic

Engineer, Planning Division, 1/9/2009

2. Gannett Fleming, Fort Carson, Colorado, Comprehensive Transportation Study (2008 Update)

3. The Weather Warehouse, Colorado Springs Municipal Airport 1/1/1988 - 1/1/2008

http://weather-warehouse.com/

4. American Automobile Association, Cost of Operating a New Vehicle Rises in 2008, 5/5/2008

5. Litman, Todd, Transportation Cost and Benefit Analysis, Victoria Transport Policy Institute, January, 2009.

6. Muller, Peter J., Personal Rapid Transit Safety and Security. TRB Paper No. 07-0907, 2007.

7.Cambridge Systematics, Inc., Crashes vs. Congestion - What's the Cost to Society?, prepared for AAA 3/5/2008.

8.CE News, Salt Lake Transit Project Gets Federal Boost, February, 2009

9. The Washington Post, U.S. Transportation Chief Backs Dulles Rail Project 1/8/2009 